Chirurgia (2021) 116: 261-270

No. 3, May-June

Copyright@ Celsius

http://dx.doi.org/10.21614/chirurgia.116.3.261

\title{
Safety and Feasibility of Robotic-Assisted Drainage of Symptomatic Pancreatic Pseudocysts: A Case-Series Analysis (with video)
}

\author{
Marco V. Marino ${ }^{1,2,3^{*}}$, Adrian Kah Heng Chiow ${ }^{4}$, Antonello Mirabella1', Olexii Potapov ${ }^{5}$, Gianpaolo Vaccarella1, \\ Mario Adelfio Latteri ${ }^{3}$, Andrzej Lech Komorowski ${ }^{6}$
}

${ }^{1}$ General and Emergency Surgery Department, Azienda Ospedaliera, Ospedali Riuniti Villa Sofia-Cervello, Palermo, Italy

${ }^{2}$ General Surgery Department, Hospital Universitario Marques de Valdecilla, Santander, Spain ${ }^{3}$ General and Oncologic Surgery Department, Policlinico Universitario P. Giaccone, Palermo, Italy

${ }^{4}$ Hepatopancreatobiliary Unit, Department of Surgery, Changi General Hospital, Singapore

${ }^{5}$ Minimally Invasive Surgery Department, Center for Innovative Medical Technologies of the National Academy of Sciences of Ukraine, Kiev, Ukraine

${ }^{6}$ Department of Surgery, College of Medicine, University of Rzeszów, Rzeszów, Poland

*Corresponding author:

Marco V. Marino, MD PhD FEBS FICS FACS

Via Stefano Pellegrino 1, Marsala (TP), 91025, Italy

Email: marco.vito.marino@gmail.com
Received: 29.03.2021 Accepted: 25.05 .2021

\section{Rezumat}

Siguranț și fezabilitatea drenajului robotic al pseudochisturilor pancreatice simptomatice: o serie de cazuri

Context:Tratamentul chirurgical al pseudochisturilor pancreatice (PP) al căror management conservator eşuează a evoluat de la abordul agresiv deschis, la cel minim invaziv. Aplicarea chirurgiei robotice în acest context este putin raportată. Scopul acestui studiu este de a analiza siguranța şi fezabilitatea abordului robotic pentru drenajul pseudochistului pancreatic.

Metode:Acest studiu este de tip retrospectiv, unicentric şi include o serie de pacienți consecutivi la care s-au practicat intervenții chirurgicale asistate robotic pentru drenajul PP, într-un centru universitar terțiar.

Rezultate: Studiul evaluează un număr de 14 pacienți la s-a practicat chisto-gastrostomie $(n=10)$ şi chisto-jejunostomie RouxEn-Y (n=4). Opt pacienți au avut în antecedente pancreatită biliară şi 3 pacienți pancreatită alcoolică. Dimensiunea medie a pseudochisturilor a fost de $8,9 \pm 1 \mathrm{~cm}$ şi $57,1 \%$ dintre acestea au fost localizate la nivelul corpului pancreatic. Timpul operator total a fost de $135 \pm 34$ de minute. $\mathrm{Nu}$ au existat conversii la operatii deschise. Rata generală de succes a fost de $92,8 \%$, în timp ce rata primară de succes a fost de $85,7 \%$. Rata de morbiditate majoră a 
fost de 14,3\%, iar mortalitatea la 30 de zile a fost 0 . Durata medie de spitalizare postoperatorie a fost de $7 \pm 3$ zile. Recurența PP a fost înregistrată într-un singur caz la care s-a practicat drenaj endoscopic, fără recidivă ulterioară.

Concluzii: Abordarea robotică pentru drenarea PP simptomatic este sigură şi fezabilă şi poate fi considerată o procedură viabilă la pacienți atent selectați.

Cuvinte cheie: colecții pancreatice, pseudochisturi pancreatice, cisto-gastrostomie robotică

\begin{abstract}
Background: The surgical treatment of pancreatic pseudocysts (PPs) in patients who fail nonoperative management has evolved from aggressive open to a minimally invasive approach. The application of robotic surgery in this setting is scarcely reported. The aim of this study is to analyze the safety and feasibility of the robotic approach to pancreatic pseudocyst drainage.

Methods: A single centre retrospective review of consecutive patients undergoing robotic-assisted pancreatic pseudocyst surgeries in an academic tertiary institution was performed.

Results: There were 14 patients studied, of whom 10 underwent cystogastrostomy and 4 Roux-EnY cystojejunostomy. Eight patients had gallstone pancreatitis and 3 patients alcoholic pancreatitis. The mean size of cyst was $8.9 \pm 1 \mathrm{~cm}$ and $57.1 \%$ located at the pancreatic body. The overall operative time of the procedure was $135 \pm 34$ minutes. There were no open conversions. The overall success rate was $92.8 \%$, while the primary success rate $85.7 \%$. The major morbidity rate was $14.3 \%$ and there was no 30 -day mortality. The mean post-operative hospital stay was $7 \pm 3$ days with one recurrence of the pancreatic pseudocyst on follow-up requiring endoscopic drainage without further recurrence. Conclusions: The robotic approach for the drainage of symptomatic pancreatic pseudocyst is safe and feasible and can be considered as a viable modality for operative intervention in well-selected patients
\end{abstract}

Key words: pancreatic fluid collections, pancreatic pseudocysts, robotic cystogastrostomy

\section{Introduction}

Pancreatic pseudocysts (PPs) represent a late complication of pancreatic fluid collections according to the revised Atlanta classification criteria (1). They are generally homogeneous, localized and sterile, surrounded by a welldefined wall of fibrous or granulation tissue, which developed as a sequela of interstitial edematous pancreatitis (2).

In 8 to $70 \%$ of cases, $\mathrm{PPs}$ regress spontaneously within 4-6 weeks (3-4). Intervention is generally considered for the treatment of PPs that fail to resolve after a period of conservative management (5), in case of large $(>6 \mathrm{~cm})$ and rapidly growing $\mathrm{PPs}$ associated with persistent symptoms or when chronic epigastric pain or life-threatening complications occur (6). The goal of the operative intervention is to provide a pathway to internal drainage thus allowing the pseudocyst cavity to collapse; it can be performed through a percutaneous, endoscopic or surgical approach (7).

Open surgery was the standard treatment for PPs since its first description in 1931 by Jurasz (8). In recent years, treatment has evolved from aggressive open surgery to a more conservative approach with minimally invasive techniques, including laparoscopic and endoscopic drainage, that have been increasingly reported with lesser morbidity and mortality in comparison with open approach (9-10). The current data show that endoscopic internal drainage is a safe method 
(11) and it is considered as a first-line treatment for PPs (12). It can be achieved through a transmural, transpapillary, or combined approach (13).

Similarly, several laparoscopic approaches for internal drainage have been described including cystogastrostomy, cystoduodenostomy, and cystojejunostomy (14). Depending on the location of the pseudocyst, it can be accessed through the anterior wall of the stomach/ duodenum, the lesser sac or by an endogastric approach (15).

The robotic approach may provide potential advantages over traditional laparoscopic technique in terms of microsuturing and microdissection capabilities, but its application in the setting of pancreatic fluid collections treatment is scarcely reported (16-18).

To date, few articles have investigated the use of the robotic system for surgical drainage of PPs. The aim of this study is to analyze the safety and feasibility of robotic-assisted drainage for the treatment of symptomatic PPs.

\section{Methods}

A retrospective review was performed of all consecutive patients who underwent robotic PPs drainage between March 2016 and June 2019 at General Surgery Department of Ospedali Riuniti, Palermo, Italy.

Study exclusion criteria are illustrated in the Table 1. All clinical cases were discussed during the weekly multidisciplinary meeting and all patients were managed according to an internal predefined protocol (Fig. 1). The surgical approach was preferred over the endoscopy in case of diagnosis of bile duct or duodenal stenosis, evidence of a necrotic component, or in case of a large cyst that was non-adherent to the posterior wall of the stomach or lack of a proper endoscopic ultrasound (EUS) window to perform an endoscopic procedure. A robot-assisted cystogastrostomy was performed in case of retro gastric cyst while large cysts bulging through the transverse mesocolon were drained by cystojejunostomy.

Blood tests including tumor markers (CEA and CA 19-9), as well as contrast-enhanced Computed Tomography (CT) scan were routinely performed on patient admission for pancreatitis and one week after the index scan. Imaging was evaluated by radiologists specialized in pancreatic diseases in order to assess the size and location of pancreatic collections, to differentiate between PPs and walled-off necrosis (WONs) according to the Revised Atlanta classification criteria and to detect potential vascular complications. Abdominal ultrasonography (US) and magnetic resonance imaging (MRI) were obtained to quantify necrotic debris within the fluid collections. Endoscopic ultrasound (EUS) was done in case of unclear diagnosis of acute fluid collections (pancreatic abscesses vs. PPs). An EUS-guided diagnostic puncture was per-

Table 1. Exclusion criteria from the study

\begin{tabular}{l}
\hline Immature fluid or necrotic pancreatic collection (<6 weeks) \\
\hline PPs that arise in the setting of chronic pancreatitis or altered pancreatic duct anatomy \\
\hline Emergency operation for complicated PPs \\
(infections, bleeding, perforation, pseudoaneurysm, fistula, involvement of peri cystic vessels) \\
\hline Patients requiring an additional surgical procedure (ventral hernia, cholecystectomy) \\
\hline Signs of portal hypertension (coagulopathy) \\
\hline Suspected diagnosis of cystic neoplasia \\
\hline General unsuitability for pneumoperitoneum (cardiopulmonary), insufficiency \\
American Society of Anesthesiologists (ASA) class $>3$ \\
Patients who underwent cystoduodenostomy for cyst located around the head or uncinate process of the pancreas close \\
to the duodenum \\
\hline Patients who underwent pancreatic resection \\
PPs: Pancreatic Pseudocysts - ASA: American Society of Anesthesiologists
\end{tabular}


A

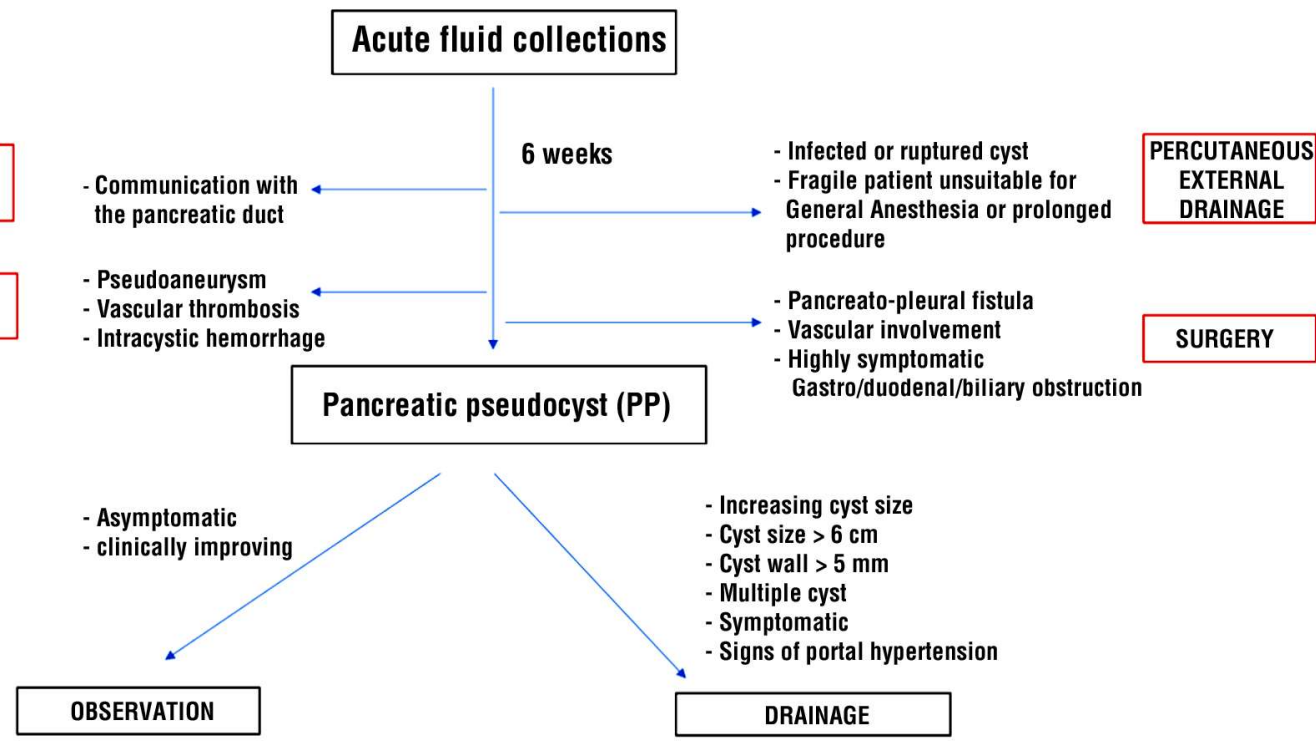

B

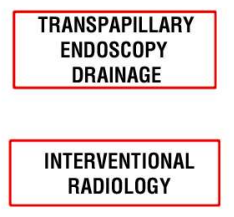

$\square$

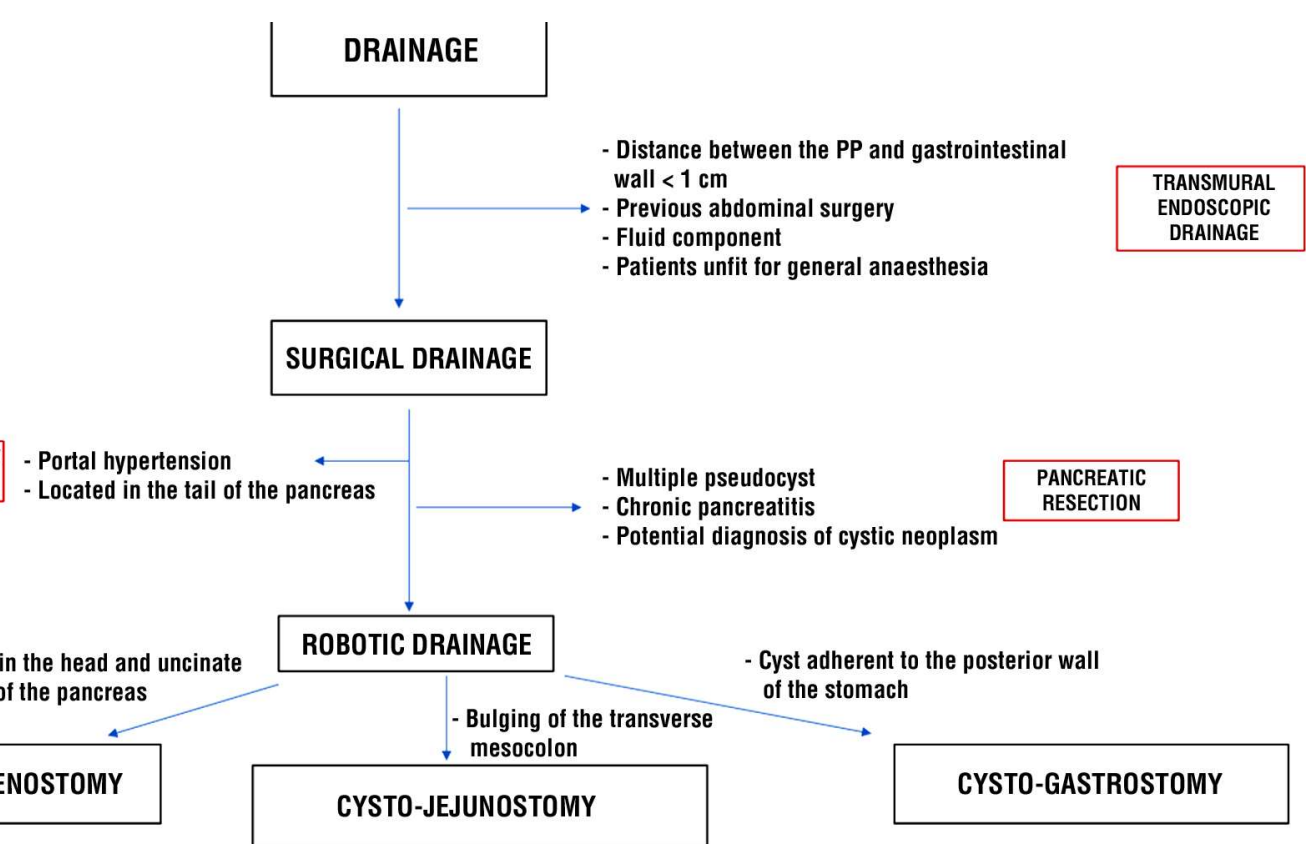

Figure 1.

formed to distinguish cystic neoplasms from PPs.

Moreover, a magnetic resonance cholangiopancreatography (MRCP) was performed to obtain information on the anatomy of the pancreatic duct, to assess its integrity and establish a possible communication with the PP. A transpapillary endoscopic retrograde cholangiopancreatography (ERCP) was per- formed for the placement of a bridge transpapillary stent, when a partial pancreatic duct disruption with leak, or a pancreatic duct stricture was diagnosed.

The operating time was reported as time from skin incision until skin closure. Intraoperative blood loss was quantified by measuring the amount of fluid obtained from the suction device. Conversion in the robotic 
group was intended as conversion to open surgery and defined as the inability to complete the operation using the robotic approach. All 30days postoperative complications were graded according to the Clavien-Dindo classification (19). Major complications were defined as grade $\geq 3$.

For patients with multiple complications, both complications were considered for the analysis. Postoperative pancreatic fistula (POPF), postoperative hemorrhage and delayed gastric emptying were defined and graded per the International Study Group in Pancreatic Surgery (ISGPS) classification (20-22).

The post-operative pain was evaluated according to the Numeric Rating Scale (NRS11) (23). The NRS-11 scale was reported in a questionnaire by each patient on postoperative day 2.

Primary therapeutic success was defined as complete resolution of the PP by the intended modality and confirmed on imaging method with resolution of symptoms after 4 weeks from the intervention. Overall success rate was defined as clinical and radiological PP resolution at the last clinical follow-up assessment regardless of the number of interventions. Reintervention was defined as the need for repeated intervention due to persistent symptoms. Recurrence was defined as the detection of a new fluid collection by imaging studies following prior resolution or as reappearance of symptoms after resolution.

Readmission and perioperative mortality were considered as those occurring during the same hospital stay or within 30 days after discharge following primary drainage procedure.

\section{Surgical Technique}

\section{Robotic-assisted Cystogastrostomy (Fig. 1A)}

The patient is placed in a supine reverse Trendelenburg position, with left side elevated. After pneumoperitoneum creation, four 8-mm robotic ports and one $11-\mathrm{mm}$ assistant laparoscopic port are placed.

The da Vinci Si or Xi Surgical System (Intuitive Surgical, Sunnyvale, CA, USA) were used to perform the surgeries. The stomach is opened on the anterior wall using Hot Shears ${ }^{\mathrm{TM}}$ (Monopolar Curved Scissors). The posterior wall is opened over the pseudocyst area after the confirmation of the location of the pseudocyst through the intraoperative ultrasound. The cavity is inspected, and any necrotic pancreatic tissue is debrided if present. A portion of the pseudocyst wall is sent for histological examination. The cystogastrostomy is fashioned using a robotic stapler or by hand-sewn anastomosis with a barbed suture. A nasogastric tube is directed into the PP cavity. The anterior gastrotomy in closed in a single-layer using 4-0 V-Loc ${ }^{\mathrm{TM}}$ suture. An air test is performed to confirm that there is no leak at the cystogastrotomy site.

\section{Robotic-assisted Cystojejunostomy (Fig. 1B)}

The transverse mesocolon is lifted and the jejunum is transected by a robotic stapler 20 $\mathrm{cm}$ from the ligament of Treitz. The proximal jejunum is anastomosed to the Roux limb 60 $\mathrm{cm}$ distally to the transected limb via $60 \mathrm{~mm}$ Robotic stapler (blue load).

The distal end is brought up to the cyst, the location of which is assessed through an intraoperative ultrasound probe. The jejunal wall and the pseudocyst cavity are both opened for $3-4 \mathrm{~cm}$ and a biopsy is taken from the cyst wall. A single layer cystojejunostomy anastomosis is performed by two 3-0 barbed running sutures.

In both techniques, a perianastomotic drain is placed. If not previously performed, a cholecystectomy is carried out for all patients with a previous stone-induced pancreatitis.

\section{Postoperative Management}

The nasogastric tube is removed on postoperative day 1 , and the patient starts a clear liquid diet. Antibiotic-therapy is continued during the course of the hospitalization. A follow-up visit is scheduled at the outpatient clinic at 1 , 3 , and then 6 months after surgery and yearly thereafter. A CT-scan and clinical examination 
are performed at 3 and 6 months after surgery. At 3 months follow-up in patients who underwent endoscopic treatment, the transmural stents are removed in case of collections resolution.

\section{Statistical Analysis}

Descriptive data are presented as mean \pm standard deviation (SD) and categorical data as frequencies and percentages. Categorical variables were tested using the chi-square, and continuous variables were compared using Student's t test. All statistical analyses were performed using SPSS version 19.0. A 95\% confidence interval (CI) of the difference in proportion was calculated. A p value of 0.05 or less was considered statistically significant.

\section{Results}

A total of fourteen patients $(n=14)$ were enrolled in the study. The robotic procedures included ten cystogastrostomy and four Rouxen-Y cystojejunostomy (Table 2).

The leading cause of pancreatic pseudocysts was biliary pancreatitis (8 out of 14 patients, $57.1 \%$ ).

The most common indication for roboticassisted cystogastrostomy was early satiety associated with a gastric outlet obstruction (50\%), while abdominal pain was the second indication $(21.4 \%)$. The overall most common clinical presentation was abdominal distension/ mass (35.7\%).

The robotic procedure was associated with an overall operative time of $135 \pm 34 \mathrm{~min}$. The overall success rate was $92.8 \%$ while the primary success rate was $85.7 \%$.

Of the two failures of the robotic procedure, one patient was converted to laparoscopic cystojejunostomy due to the firm adhesions in the sub-mesocolic compartment which hindered the mobilization of the jejunal loop by the robotic instruments. In another patient, due to signs of sepsis which developed from incomplete resolution of the pancreatic fluid collection before discharge, additional percutaneous drainage for residual collections with
Table 2. Demographic and preoperative characteristics of the patients involved in the study

\begin{tabular}{|c|c|}
\hline & $\begin{array}{l}\text { Robotic group } \\
\quad(n=14)\end{array}$ \\
\hline Age (years) mean \pm SD & $45.9 \pm 7.5$ \\
\hline \multicolumn{2}{|l|}{ Sex, n (\%) } \\
\hline - Male & $8(57.2 \%)$ \\
\hline - Female & $6(42.8 \%)$ \\
\hline $\mathrm{BMI}\left(\mathrm{Kg} / \mathrm{m}^{2}\right)$ mean $\pm \mathrm{SD}$ & $27.8 \pm 1.8$ \\
\hline \multicolumn{2}{|l|}{ Comorbidities, n (\%) } \\
\hline - Diabetes & $3(21.4 \%)$ \\
\hline - Cardiovascular disease & $2(14.4 \%)$ \\
\hline - Pulmonary disease & $1(7.1 \%)$ \\
\hline - Chronic renal insufficiency & $1(7.1 \%)$ \\
\hline ASA score, mean \pm SD & $2.7 \pm 0.7$ \\
\hline \multicolumn{2}{|l|}{ ASA score, $n(\%)$} \\
\hline-1 & $2(14.3 \%)$ \\
\hline$-\|$ & $6(42.8 \%)$ \\
\hline$-\mid I I$ & $6(42.8 \%)$ \\
\hline \multicolumn{2}{|l|}{ Main Symptom } \\
\hline - Abdominal Pain & $3(21.4 \%)$ \\
\hline - Nausea & $2(14.3 \%)$ \\
\hline - Early satiety & $7(50 \%)$ \\
\hline - Regurgitation & $1(7.1 \%)$ \\
\hline - Illness / Fever & $1(7.1 \%)$ \\
\hline \multicolumn{2}{|l|}{ Main Signs: } \\
\hline - Abdominal distension/mass & $5(35.7 \%)$ \\
\hline - Vomiting & $3(21.4 \%)$ \\
\hline - Jaundice & $2(14.3 \%)$ \\
\hline - Weight loss & $2(14.3 \%)$ \\
\hline - Melena/Hematemesis & $1(7.1 \%)$ \\
\hline - Ascites & $1(7.1 \%)$ \\
\hline Previous surgery, $\mathrm{n}(\%)$ & $2(14.3 \%)$ \\
\hline \multicolumn{2}{|l|}{ Etiology of Pancreatitis, n (\%) } \\
\hline - Biliary/Gallstones & $8(57.1 \%)$ \\
\hline - Alcoholic & $3(21.4 \%)$ \\
\hline - Trauma & $1(7.1 \%)$ \\
\hline - Upper G.I. surgery & $1(7.1 \%)$ \\
\hline - Idiopathic & $1(7.1 \%)$ \\
\hline Mean size, $\mathrm{cm}$, mean $\pm \mathrm{SD}$ & $8.9 \pm 0.9$ \\
\hline \multicolumn{2}{|l|}{ Site of the cyst, $n(\%)$} \\
\hline - Head & $1(7.1 \%)$ \\
\hline - Body & $8(57.1 \%)$ \\
\hline - Tail & $5(35.7 \%)$ \\
\hline $\begin{array}{l}\text { Interval between onset of AP and intervention, } \\
\text { days, mean } \pm S D\end{array}$ & $72 \pm 24$ \\
\hline Preoperative antibiotic therapy, n (\%) & $5(35.7 \%)$ \\
\hline
\end{tabular}

SD: Standard Deviation - BMI: Body Mass Index - ASA: American Society of Anesthesiologists - G.I.: Gastrointestinal - AP: Acute Pancreatitis

lavage of area of colliquations was required.

The overall morbidity rate was $28.6 \%$ with $14.3 \%$ major morbidity. Two major complications occurred. One patient developed a symptomatic splenic artery pseudoaneurysm which was diagnosed on postoperative day 6 during an ultrasound examination due to abdominal pain which required subsequent radiologic embolization. A patient who underwent cysto- 
Table 3. Postoperative outcomes of patients who underwent endoscopic versus robotic-assisted drainage of pancreatic pseudocysts (PPs)

\begin{tabular}{lc}
\hline Variables & $\begin{array}{c}\text { Robotic group } \\
(\mathbf{n = 1 4 )}\end{array}$ \\
\hline Operative time, min, mean \pm SD & $135 \pm 34$ \\
\hline Estimated blood loss, mL, mean \pm SD & $75 \pm 30$ \\
\hline Primary success rate (after index procedure), $\mathrm{n}(\%)$ & $12(85.7 \%)$ \\
\hline Overall success rate, $\mathrm{n}(\%)$ & $13(92.8 \%)$ \\
\hline Conversion to laparoscopic drainage, $\mathrm{n}(\%)$ & $1(7.1 \%)$ \\
\hline Median time to oral feeding, hours, mean $\pm \mathrm{SD}$ & $46 \pm 13$ \\
\hline NRS (n), mean \pm SD & $5.9 \pm 1.9$ \\
\hline Morbidity, $\mathrm{n}$ (\%) & $4(28.8 \%)$ \\
- Minor & 2 \\
- Major (CDC $\geq 3$ ) & 2 \\
Splenic artery pseudo-aneurysm (3A) & 1 \\
Internal hernia (3B) & 1 \\
\hline Need for additional procedure, $\mathrm{n}(\%)$ & $2(14.3 \%)$ \\
- Endoscopic drainage/lavage & nil \\
- Percutaneous drainage & 1 \\
- Laparoscopic conversion drainage & 1 \\
\hline Hospital stay (days), mean \pm SD & $7 \pm 3$ \\
\hline Recurrence rate, $\mathrm{n}$ (\%) & $1(7.1 \%)$ \\
\hline Mortality, $\mathrm{n}(\%)$ & nil \\
\hline NRS: Numerical Rating Scale - CDC: Clavien Dindo Classification
\end{tabular}

jejunostomy had prolonged post-operative ileus due to an internal hernia which required reoperation and restoration of the digestive tract continuity.

The post-operative pain based on NRS score was $5.9 \pm 1.9$ (Table 3).

The mean follow-up duration was 10 months (4-28). At 3-months follow-up partial resolution of a PP was observed in one patient. The patient was readmitted and underwent repeat endoscopic drainage with lavage and stent replacement by a self-expandable metallic stent.

\section{Discussion}

Pancreatic Pseudocysts (PPs) are matured peripancreatic fluid collections, resulting from pancreatitis, trauma or pancreatic surgery (3, 24) which develop in 7-10\% of patients after acute pancreatitis, and in $10-30 \%$ after chronic interstitial edematous pancreatitis. Most of the pancreatic fluid collections resolve spontaneously (5) and their management is based on conservative treatment for $4^{-} 6$ weeks from the onset of acute pancreatitis, during which nutritional support, low fat diet, analgesics, antiemetics or antibiotics could be administered (25). A surgical intervention is required only in 10 to $20 \%$ of cases (26).

Over the last decades, treatment of PPs has evolved from aggressive open surgery towards less invasive approaches thanks to the advent of minimally invasive techniques such as endoscopic or laparoscopic surgery (4). Despite the promising results offered by robotic surgery for the treatment of pancreatic neoplasm, the low incidence of PPs (1.6-4.5\% per 100.000 adults per year) (27) and the lack of clear advantage of robotic surgery in the setting of emergency surgery limits the application of robotic approach for the treatment of this condition.

To the best of our knowledge, this paper represents one of the biggest case series which analyzes the outcome of a group of patients who underwent robotic PPs drainage with either cystogastrostomy or cystojejunostomy. Our results show that these surgeries can be performed successfully via the robotic approach with high percentage of primary success and overall success. Major morbidity rate was low at $14.3 \%$ with no mortalities. In our experience, intra-abdominal infections and iatrogenic injury were the most common complications of these robotic assisted procedures (28). Our results are comparable to results of a recently published series of delayed robotic cystogastrostomy for walled off pancreatic necrosis (29). The authors reported a complication rate of $38 \%$ with a mean LOS of 6.4 days and no mortality at 90 days. Taken together, our series demonstrates that in wellselected patients, robotic approach can be a viable alternative for patients considered for operative intervention for these indications with encouraging outcomes.

Although some authors have reported that endoscopic drainage of PFCs had shown efficacy and morbidity rate comparable to that of surgery (30) with benefits in terms of hospital stay reduction, operative time, and treatment cost $(11,31)$, unfortunately, it is associated with important failure rate of clearance of the cavity in cases of unfavorable anatomy. In particular, in patients with necrotic 
tissue within PPs, the endoscopic approach is associated with a significant intervention rate (17-27\%) due to obstructed stents (32). Furthermore, it is associated with other complications such as bleeding and perforation, often necessitating urgent intervention (33).

In this context and in institutions lacking expertise in the field of advanced endoscopy or interventional radiology, surgical therapy is still considered the treatment of choice.

The role of laparoscopic surgery in the treatment of pancreatic fluid collections is constantly evolving (30). In a recent nationwide, population-based database including a total of 7060 patients, the laparoscopic approach showed to be associated with lower transfusion rate, post-operative morbidity, shorter mean length of hospitalization ( 7 vs $11, \mathrm{p}=0.009$ ), lower total charge, shorter operative time (32), when compared with the open counterpart.

In a recent randomized trial, the initial success rate at 4 weeks was comparable after the index intervention between laparoscopic and endoscopic PPs drainage (83.3\% vs $76.6 \%$, $\mathrm{p}=0.7$ ). Similarly, the overall clinical success rate and the complication rate were comparable $(93.3 \%$ vs $90 \%, \mathrm{p}=1.0$ and 19 vs $9, \mathrm{p}=0.01$, respectively). Importantly, the number of repeat procedures were higher in the endoscopic group (15 vs $3, p=0.0001$ ) (35).

Similar findings were confirmed in a systematic review including 118 laparoscopic and 569 endoscopic patients, where laparoscopic series did demonstrate comparable results with respect to endoscopic approach in terms of initial success rate (98.3\% vs $80.8 \%$ ), recurrence rate $(2.5 \%$ vs $14.4 \%)$, morbidity ( $4 \%$ vs $12 \%$ ), and mortality ( $0 \%$ vs $0.4 \%$ ) (36).

Melman et al. found no difference in complication rates and overall success rate among surgical versus endoscopic approach (31.5\% vs $15.6 \%$ and $92.8 \%$ vs $84.6 \%$ respec- $^{-}$ tively), but the former was associated with a higher primary success rate in comparison to endoscopy (87.5\% vs 51.1\%) (3).

The surgical approach offers in fact the opportunity to create a wide anastomotic opening of the desired size thus avoiding progressive dilatation and stent placement which lead to far lower recurrence rate in comparison to endoscopy and more effective control of any bleeding from the stomach wall as well as debridement (37). A recent systematic review including 342 patients concluded that there is no significant difference between surgical and endoscopic treatment success rates, adverse events (19.7\% vs $11.5 \%)$, and recurrence for pancreatic pseudocyst while the length of stay was lower in the endoscopic group (38).

The laparoscopic drainage of PFCs seems to be technically challenging due to the complexity in fashioning an anastomosis in a narrow and deep anatomical area; the lack of dexterity of the laparoscopic instruments hindered its widespread adoption (39).

The robotic platform offers some advantages over traditional laparoscopic surgery in terms of micro suturing capabilities, the highdefinition 3-dimensional visualization and the endo-wrist instruments which may facilitate the creation of a complex anastomosis (40-42). Recently, the adoption of the Endowrist robotic stapler enhanced the precision of anastomosis located in deep area as the retroperitoneum. Finally, the software for the intraoperative ultrasound (TilePro) can be integrated in the robotic system and it can used to locate the collections thus tailoring the surgical approach (anterior or posterior approach). In the authors' opinion, the lack of tactile feedback which can be considered a potential drawback when an inflamed or fragile tissue is manipulated, is counterbalanced by the enhanced visualization offered by the three-dimensional view of pseudocyst cavity to facilitate its debridement.

The robotic approach may represent an attractive alternative, but unfortunately only few authors reported their experience in robotic PPs treatment, and most of them are limited to small case series $(17-18,42)$.

Considering our early experience, the total hospital cost was not analyzed for our cohort of patients. The experience of other authors seems to suggest that endoscopic approach is associated with lower hospital cost when compared with surgery (30). Conceivably, with 
the advent of newer competing systems for robotic surgery becoming available on the market, this cost differential may narrow although further studies are required in this area. With increasing expertise, this may lead to greater utilization of this promising platform in difficult operative scenarios in the management of pancreatic fluid collections in the near future.

\section{Conclusion}

Robotic surgery is a safe and feasible approach in the management of patients with pancreatic pseudocyst requiring surgical intervention.

\section{Author Contributions}

Conception and design: MVM, AKHC, OP,GV, MAL. Administrative support: OP, AKHC, GV, ADL. Provision of study materials or patients: MVM, AM,OP, GV, MAL. Collection and assembly of data: MVM, AM, OP, GV, MAL. Data analysis and interpretation: All authors. Manuscript writing: All authors. Final approval of manuscript: All authors.

\section{Footnote}

The authors are accountable for all aspects of the work in ensuring that questions related to the accuracy or integrity of any part of the work are appropriately investigated and resolved.

\section{Ethics Approval}

The study was conducted in accordance with the provisions of the Declaration of Helsinki with approval of the institutional review board of the hospital and with informed consent from patients involved in the study.

\section{Conflict of Interest}

The author Marco V. Marino is Proctor and Advisor of CAVA Robotics Inc. All other authors declare they have no conflict of interest to disclose.

\section{Source of Funding}

The study did not receive any financial support.

\section{Availability of Data and Material}

Data available on request.

\section{References}

1. Banks PA, Bollen TL, Dervenis C, Gooszen HG, Johnson CD, Sarr MG, et al. Acute Pancreatitis Classification Working Group. Classification of acute pancreatitis--2012: revision of the Atlanta classification and definitions by international consensus. Gut. 2013;62(1):102-11.

2. Bezmarevic M, van Dijk SM, Voermans RP, van Santvoort HC, Besselink MG. Management of (Peri)Pancreatic Collections in Acute Pancreatitis. Visc Med. 2019;35(2):91-96.

3. Melman L, Azar R, Beddow K, L Michael Brunt, Halpin VJ, Eagon JC, et al. Primary and overall success rates for clinical outcomes after laparoscopic, endoscopic, and open pancreatic cystgastrostomy for pancreatic pseudocysts. Surg Endosc. 2009;23(2):267-71.

4. Agalianos C, Passas I, Sideris I, Davides D, Dervenis C. Review of management options for pancreatic pseudocysts. Transl Gastroenterol. 2018;21;3:18.

5. Vitas GJ, Sarr MG. Selected management of pancreatic pseudocysts: operative versus expectant management. Surgery. 1992;111(2):123-30.

6. Manrai M, Kochhar R, Gupta V, Yadav TD, Dhaka N, Kalra N, et al. Outcome of Acute Pancreatic and Peripancreatic Collections Occurring in Patients with Acute Pancreatitis. Ann Surg. 2018;267(2):357-363.

7. Tyberg A, Karia K, Gabr M, Desai A, Doshi R, Gaidhane M, et al. Management of pancreatic fluid collections: A comprehensive review of the literature. World J Gastroenterol. 2016; 22(7):2256-70.

8. Karavias T, Dollinger P, Häring R. Cystogastrostomy in the Treatment of Pancreatic Pseudocysts. In: Beger H.G., Büchler M., Malfertheiner P, editors. Standards in Pancreatic Surgery. Berlin, Heidelberg: Springer; 1993

9. Van Brunschot S, Hollemans RA, Bakker OJ, Besselink MG, Baron TH, Beger $\mathrm{HG}$, et al. Minimally invasive and endoscopic versus open necrosectomy for necrotising pancreatitis: a pooled analysis of individual data for 1980 patients. Gut. 2018;67(4):697-706.

10. Wang $Y$, Omar $Y A$, Agrawal R, Gong Z. Comparison of treatment modalities in pancreatic pseudocyst: A population-based study. World J Gastrointest Surg. 2019:11(9):365-372.

11. Redwan AA, Hamad MA, Omar MA. Pancreatic Pseudocyst Dilemma: Cumulative Multicenter Experience in Management Using Endoscopy, Laparoscopy, and Open Surgery. J Laparoendosc Adv Surg Tech A. 2017; 27(10):1022-1030.

12. Pan G, Wan MH, Xie KL, Li W, Hu WM, Liu XB, et al. Classification and Management of Pancreatic Pseudocysts. Medicine (Baltimore). 2015; 94(24): $\mathrm{e} 960$

13. Lin H, Zhan XB, Sun SY, Yang XJ, Jin ZD, Zou DW, et al. Stent selection for endoscopic ultrasound-guided drainage of pancreatic fluid collections: a multicenter study in china. Gastroenterol Res Pract. 2014;2014:193562.

14. Bansal VK, Krishna A, Prajapati OP, Baksi A, Kumar S, Garg P, et al. Outcomes following laparoscopic internal drainage of walled off necrosis of pancreas: experience of 134 cases from a tertiary care centre. Surg Endosc. 2020; 34(11);5117-5121.

15. Khaled YS, Malde DJ, Packer J, Fox T, Laftsidis P, Ajala-Agbo T, et al. Laparoscopic versus open cysto-gastrostomy for pancreatic pseudocysts: a case-matched comparative study. J Hepatobiliary Pancreat Sci. 2014; 21(11):818-23 
16. Kirks RC Jr, Sola R Jr, lannitti DA, Martinie JB, Vrochides D. Robotic transgastric cystgastro-stomy and pancreatic debridement in the management of pancreatic fluid collections following acute pancreatitis. J Vis Surg. 2016; 26;2:127.

17. Nassour I, Ramzan Z, Kukreja S. Robotic cystogastrostomy and debridement of walled-off pancreatic necrosis. J Robot Surg. 2016;10(3):279-82.

18. Cardenas A, Abrams A, Ong E, Jie T. Robotic-assisted cystogastrostomy for a patient with a pancreatic pseudocyst. J Robot Surg. 2014;8(2):181-4.

19. Dindo D, Demartines N, Clavien PA. Classification of surgical complications: a new proposal with evaluation in a cohort of 6336 patients and results of a survey. Ann Surg. 2004;240(2):205-13

20. Bassi C, Marchegiani G, Dervenis C, Sarr M, Abu Hilal M, Adham M, et al International Study Group on Pancreatic Surgery (ISGPS) (2017) The 2016 update of the International Study Group (ISGPS) definition and grading of postoperative pancreatic fistula: 11 Years After. Surgery. 2017 161(3):584-591

21. Wente MN, Bassi C, Dervenis C, Fingerhut A, Gouma DJ, Izbicki JR, et al Delayed gastric emptying (DGE) after pancreatic surgery: a suggested definition by the International Study Group of Pancreatic Surgery (ISGPS). Surgery. 2007;142(5):761-8.

22. Wente MN, Veit JA, Bassi C, Dervenis C, Fingerhut A, Gouma DJ, et al Postpancreatectomy hemorrhage (PPH): An International Study Group of Pancreatic Surgery (ISGPS) definition. Surgery. 2007;142(1):20-5.

23. Farrar JT, Young JP Jr, LaMoreaux L, Werth JL, Poole MR. Clinical importance of changes in chronic pain intensity measured on an 11-point numerical pain rating scale. Pain 2001;94(2):149-58

23. Bliss LA, Yang CJ, Eskander MF, de Geus SWL, Callery MP, Kent TS, et al. Surgical management of chronic pancreatitis: current utilization in the United States. HPB (Oxford) 2015;17(9):804-10.

24. Bradley EL $3^{\text {rd }}$. The natural and unnatural history of pancreatic fluid collections associated with acute pancreatitis. Dig Dis Sci. 2014;59(5):908-10.

25. Habashi S, Draganov PV. Pancreatic pseudocyst. World J Gastroenterol 2009;15(1):38-47

26. Andrén-Sandberg A, Ansorge C, Eiriksson K, Glomsaker T, Maleckas A Treatment of pancreatic pseudocysts. Scand J Surg. 2005;94(2):165-75.

27. Khanna AK, Tiwary SK, Kumar P. Pancreatic pseudocyst: therapeutic dilemma. Int J Inflam. 2012;2012:279476.

28. Marino MV, Mitus JW, Vaccarella G, Potapov 0, Antonello M. Complication profile after robotic pancreatic surgery. Panstwo I Spoleczenstwo. 2020 (XX)2:51-63

29. Picken RC, Sulzer JK, Cochran A, Vrochides D, Martinie JB, Baker EH, et al Retrospective Validation of an algorithmic treatment pathway for Necrotizing Pancreatitis. Am Surg. 2019;85(8):840-847.
30. Shahid H. Endoscopic management of pancreatic fluid collections. Transl Gastroenterol Hepatol. 2019;26:4:15.

31. Varadarajulu S, Bang JY, Sutton BS, Trevino JM, Christein JD, Wilcox CM. Equal efficacy of endoscopic and surgical cystogastrostomy for pancreatic pseudocyst drainage in a randomized trial. Gastroenterology. 2013;145(3): 583-90.e1.

32. Fabbri C, Luigiano C, Maimone A, Polifemo AM, Tarantino I, Cennamo V. Endoscopic ultrasound-guided drainage of pancreatic fluid collections. World J Gastrointest Endosc. 2012;4(11):479-88.

33. Van Brunschot S, Fockens P, Bakker OJ, Besselink MG, Voermans RP, Poley JW, et al. Endoscopic transluminal necrosectomy in necrotising pancreatitis: a systematic review. Surg Endosc. 2014;28(5):1425-38.

34. Wang Y, Omar YA, Agrawal R, Gong Z. Comparison of treatment modalities in pancreatic pseudocyst: A population-based study. World J Gastrointest Surg. 2019;11(9):365-372.

35. Garg PK, Meena D, Babu D, Padhan RK, Dhingra R, Krishna A, et al. Endoscopic versus laparoscopic drainage of pseudocyst and walled-off necrosis following acute pancreatitis: a randomized trial. Surg Endosc. 2020;34(3):1157-1166.

36. Aljarabah M, Ammori BJ. Laparoscopic and endoscopic approaches for drainage of pancreatic pseudocysts: a systematic review of published series. Surg Endosc 2007;21(11):1936-44

37. Cannon JW, Callery MP, Vollmer CM Jr. Diagnosis and management of pancreatic pseudocysts: what is the evidence? J Am Coll Surg. 2009; 209(3):385-93

38. Farias GFA, Bernardo WM, De Moura DTH, Guedes HG, Brunaldi VO, de C Visconti TA, et al. Endoscopic versus surgical treatment for pancreatic pseudocysts: Systematic review and meta-analysis. Medicine (Baltimore). 2019;98(8):e14255

39. Palanivelu C, Senthilkumar K, Madhankumar MV, Rajan PS, Shetty AR, Jani K, et al. Management of pancreatic pseudocyst in the era of laparoscopic surgeryexperience from a tertiary centre. Surg Endosc. 2007;21(12):2262-7.

40. Marino MV, Podda M, Pisanu A, di Saverio S, Fleitas MG. Robotic-assisted Pancreaticoduodenectomy: Technique Description and Performance Evaluation After 60 Cases. Surg Laparosc Endosc Percutan Tech 2020; 30(2):156-163

41. Marino MV, Mirabella A, Guarrasi D, Lupo M, Komorowski AL. Roboticassisted repair of iatrogenic common bile duct injury after laparoscopic cholecystectomy: Surgical technique and outcomes. Int J Med Robot. 2019;15(3):e1992.

42. Felsenreich DM, Quinterro LA, Koo DC, Gachabayov M, Matsumoto S, Dong XED. Robotic retrogastric cysto-gastrostomy for pancreatic pseudocyst - A video vignette. J Hepatobiliary Pancreat Sci. 2020;27(7):439-440. 